\title{
Publiser
}

The Graduate Program of Universitas Galuh Master of Management Studies Program (C2019

\section{Customer Loyalty: Quality of Service}

\author{
Apri Budianto ${ }^{1}$ \\ ${ }^{1}$ Management Program of Economic Faculty of Galuh University \\ email: apribudiantogaluh@gmail.com
}

\author{
Article History : \\ Recieved 7 January 2019 \\ Recieved in revished form \\ 21 January 2019 \\ Acepted 25 January 2019 \\ Available offline 29 January 2019 \\ Available online 30 Januari 2019
}

Language Transcript :

English (en)

\section{Key Words :}

The better the quality of service The higher the customer loyalty

\begin{abstract}
This article focuses on the influence of service quality on customer loyalty to modern market customers. This article is motivated by the increasing number of modern market customers caused by the quality of service that affects the increasing loyalty of customers. The formulation of the problem in this article is how the quality of service influence on customer loyalty. The working hypothesis in this article is: "Service Quality positively affects customer loyalty".The method employed in making this article was done to get a picture of the effect of service quality on customer loyalty to modern market customers. Data were collected through data collection techniques in the field using explanatory survey method. Customer loyalty is influenced by the service quality of $38.30 \%$. This means that customer loyalty is only affected a small portion of service Quality of $38.30 \%$. Thus $t_{\text {count }}>t_{\text {table }}$ was $3.421>1.667$. Then the null hypothesis $\left(H_{o}\right)$ is rejected. This means that service quality has a positive effect on customer loyalty.Service Quality positively affects customer loyalty, meaning the better the quality of service provided the more loyal customers.
\end{abstract}

\section{INTRODUCTION}

Marketing activities is a function that directly determines corporate objectives (corporate objectives) and activities that have a wide scope, because in addition to including internal as well as external company. As stated by Kotler \& Keller (2009: 6) states that "marketing is a social and managerial process whereby individuals or groups aim to meet their needs and desires through creativity, supply and exchange of product value with others". The most basic concept of marketing is how a company can meet customer needs (costumer requerement) and conduct environmental analysis (Walker, 1999: 94).

The existence of a change of trade paradigm in Indonesia market not only traditional market but also developed modern market. With the development of modern market, the core concept, trend, and marketing task also changed. The core concept of marketing is a set of concepts creating a foundation for marketing management and holistic marketing orientation (Kotler Keller, 2009: 29).

In the globalization era, there has been a very tight competition among Retail Companies, even among individuals, thus demanding innovation based competition (innovation based competition). In fact, with the growing integration of the world economy, almost all companies, especially retail businesses, will face demanding and demanding customers. Such customers always demand better quality, lower prices, timely supply, and excellent service. Thus only an efficient, effective and innovative 
retail and productive company that will remain able to survive even a winner in the competition, while those who are unable to compete will suffer a setback and not even close the possibility of becoming bankrupt.

Retail business in Indonesia has developed rapidly in recent years with various formats and types, especially the growth of minimarket either under shelter or not. This proves that the growth of trading area is increasing rapidly. This is as a result of the development of manufacturing businesses and market opportunities are quite open, as well as government efforts to encourage the development of retail business. The Government plays a role in protecting the national retail, through regulations and laws. Retail companies in Indonesia are still dominated by foreign investors, Foreign investment in Indonesia in the form of: 1) franchise system partnerships such as Body Shop, JC Penney, and Mark \& Spencer; 2) cooperative-technical cooperation such as Sogo and Seibu, and 3) joint venture partnership. (Christina Whidya Utami, 2006: 19).

Retail business is a difficult business to differentiate, hence retail requires relationship effort to realize customer retention and customer loyalty. The relationship effort is an active business of retail in contributing to customer expectations to realize customer retention through the delivery of core products and services that create sustainable relationships or create customer loyalty. Modern market that grows and develops in Indonesia generally and in Ciamis in particular consists of two forms of modern markets namely minimarkets and Department store.

The problem that can be answered through this article is the influence of service quality to the loyalty of the modern market customers. The working hypothesis in this article is: "Quality of service positively affects customer loyalty".
Based on the above problems, the authors set the title of the article as follows "Quality of Service Influential Against Loyalty of Modern Market Customers".

\section{LITERATURE REVIEW}

\subsection{The Nature of Service Quality}

The quality of service is complex and most often discussed in marketing disciplines. The quality of service described in general and thoroughly evaluated in services is even a multidimensional conception built through an evaluation of the construction of a number of service-related attributes. It is for this reason that the notion of the concept of service quality continues to evolve, especially the need for models to assess the quality of service provided by the modern market.

Taking into account the understanding of the service quality of some experts above, the factors that affect the quality of service, the target and the superior service benefits that reflect the application of service quality, the understanding related to the quality of service, and the grouping of the tasks and skills of the modern market employee, can be stated that what is meant by the quality modern market service is the level of performance excellence (performance) or action, benefits and function of modern market employees in the operations of the company to serve customer needs appropriately and satisfactorily and in accordance with customer expectations.

According Tjiptono (2007: 140) customer service perceived quality model consists of two main dimensions, namely:

1. Technical Quality (outcome dimension), related to the quality of customer perceived service output. This component can be translated into three types according to Zeithaml et al. which consists of: search quality (quality that can be evaluated before the customer 
purchase), experience quality (quality that can only be evaluated after buying or consuming customers), and credence quality (a quality that is difficult to evaluate customers even if the service has been consumed).

2. Functional Quality (process-related dimension), relating to the quality of service delivery or concerning the process of transferring the technical quality, output or outcome of services from the service provider to the customer.

The dimension of service quality is also expressed by Gronroos in Tjiptono (2007: 136), which formulates the service quality dimension as follows:

\section{Professionalism and Skills}

This first criterion is an outcome-related criteria in which the customer realizes that service providers, employees, operational systems, and physical resources possess the knowledge and skills needed to solve customer problems professionally.

\section{Attitudes and Behavior}

This criterion is a process-related criteria. Customers feel that company employees are concerned about them and are trying to help in solving their problems spontaneously and happily.

\section{Accessibility and Flexibility}

This criterion is a process-related criteria. The customer feels that the service provider, location, working hours, employees, and operational systems are designed and operated in such a way that customers can access easily. It is also designed with the intention of being flexible in customizing customer requests and desires.

\section{Realibility and Trustworthiness}

This criterion is a process-related criteria in which the customer understands that whatever happens, they can entrust everything to the service provider along with the employees and the system.

\section{Service Recovery}

The customer realizes that if there is an error or if something unexpected happens, the service provider will take immediate action to control the situation and find the right solution.

\section{Reputation and Credibility}

Tjiptono (2008: 78) states that today's superior service quality is seen as a tool to gain competitive advantage in several organizations or companies. Superior service quality and consistency can foster customer satisfaction which in turn will provide various benefits. Kotler in Tjiptono (2007: 121) states that the quality of service should start from the needs and customer satisfaction as well as positive perceptions of the quality of service.

Tanner (1998: 13, No. 6) explains that, after making a purchase, there are several possible actions that customers need to be evaluated (post purchase evaluation), namely: (1) no longer buy, (2) repeated buying (repurchase), (3) buy again repeatedly and invite others to buy the product (refferall). Buying back is done by the customer if they are satisfied, and if the product/service performance is improved according to customer's expectation, then the customer will have high loyalty to the product/service (Horovitz, 2000: 73). Roger J. Best, (2008: 38) states that the rating of customer satisfaction measurement is very dissatisfied, dissatisfied, somewhat dissatisfied, somewhat satisfied, , and (very satisfied).

\subsection{The Nature of Customer Loyalty}

Service loyalty is more likely to be felt for the customer of an organization or company than a tangible product customer, and according to Macintosh (1998) because service loyalty is more dependent on the development of interpersonal relationship 
as opposed to loyalty with tangible products. This means more service loyalty depends on the development of interpersonal relationships that are contrary to loyalty to tangible products. Furthermore, according to Zeithaml (1981) "furthermore, the influence of percerfed risk is greater in the case of service, as customer loyalty may act as a barrier to customer switching behavior". This means that the effect of greater customer loyalty is felt in service products, this is reinforced in the opinion of Snyder (1986) "indeed, it has been demontrated that loyalty is more prevalent among service customers than among the customer of tangible product". It means it has been proven that customer loyalty is more among service customers than customers of tangible products. Thus, intangible traits such as reliability and trust play a major role in fostering or maintaining loyalty.

Loyalty according to Liljander (1995) "Loyalty is frequently observed behavior" loyalty is often defined as the actual behavior that encourages the performance of service organizations, but behavioral measures such as purchasing and buying wholesale are criticized for lack of basic conceptions and have a narrow sense of view which focuses on the results of what is actually a dynamic process, for example a low degree of repeat purchase of certain services may be the result and situational factors such as infidelity, the search for variety and the lack of buyer's preferences or preferences.

Loyal customers are the most valuable asset for the company in improving the profitability of the company. To be able to make loyal customers, emphasize the importance of the company seize new customers and retain customers, need a high commitment both in terms of funds and human resources so that product quality is really in accordance with the wishes of customers. If the customer is satisfied, it is expected he will not switch to another company (Blackwell, Miniard, Engel, 2001: 273).

The marketing company's paradigm shift from satisfaction to customer loyalty is also stated by Bothe, (2000: 107) who states that "future corporate orientation is shifting from a conventional approach to contemporary appraisal." The conventional approach emphasizes customer satisfaction, cost reduction, market share and market research, while the contemporary approach focuses more on customer loyalty, customer retention, and lifelong customers. The relationship between customer satisfaction and customer loyalty according to Schnaars (1998: 204) can be divided into four groups, namely: (1) failures, ie where the level of satisfaction and loyalty is low or in this case not satisfied and not loyal ; (2) defector (crossing), namely high customer satisfaction but low loyalty; (3) forced loyalty, where customer satisfaction is low but loyalty is high. This can happen because customers feel attached to the company's loyalty promotion program; (4) successes, where the level of customer satisfaction and customer loyalty is high. Conditions such as this is very possible the occurrence of word of mouth communication (WOM) is positive for the company.

Where loyalty leads more to the behavior shown by "routine purchases based on decision-making units". Further more firmly, Griffin (2000: 35) states that customer loyalty levels can be classified into: Suspect, covering all people who may be buying company products. The company calls it suspect because they believe they will buy the company's products but they do not know anything about the company and the products it offers. Prospect, are those who have the need for a product and have the ability to get it. They already know about the company and the products it offers. Disqualified Prospect, the prospect 
who knows the existence of a company's product, but they do not "have a need" for the product, or they do not have the purchasing power to get it. " First time customer, the customer who buys for the first time. Repeat customers, customers who have purchased the same product twice, or purchased two different products on two different occasions. Clients, ie customers who buy all the products the company offers, they need. The company's relationship with this type of customer "has been very strong and lasting", they are not budging with the company's competitor's products. Advocates (advocates), ie customers of company products who encourage or encourage their friends to consume products offered by the company.

Furthermore Griffin (2000: 89) states the criteria of loyal customers are: (1) Repeat purchase (buyback); (2) Retention, where the customer only purchases products from the company; (3) Related sales of services, where customers want to utilize the same products in the future; (4) Referrals or refers to others, where customers advise others to consume products.

\section{THE METHOD}

The method employed in making this article is done to get a picture of the effect of service quality on the loyalty of modern market customers. Data were collected through data collection techniques in the field using explanatory survey method.

Based on consideration of research objectives, this research used verification and descriptive problem. The nature of verification research basically wanted to test the truth of a hypothesis implemented through data collection in the field. Given the nature of this research was descriptive and verifikatif implemented through data collection in the field, the research method used was descriptive survey method and explanatory survey method.
This type of research was causality, because it would be tested causal effect between indevenden and dependent variable. The unit of analysis in this study was individual, because only the people who made the respondents. The time horizon in this study was cross-sectional, since information from some populations (respondent sample) was collected directly at the scene empirically in order to know the opinion of some population on the object being studied.

The type of data needed in this study was primary data and secondary data. Primary data was the set of information obtained in survey by interview method and using structured questionnaire. Secondary data were obtained by reviewing data obtained from the recipient community, studying documents, research reports, publications and other literature supporting research.

According to Nasir (1999: 99), "Design research is all the necessary processes in planning and conducting research". In this research, research design used is explanatory survey (explanatory survey). In connection with this, Rusidi (2003: 38) further elaborate that xxplanatory research survey, as stated Kerlinger in Sugiyono (1988: 3) is research conducted on large and small populations, but the data studied is data from the samples taken from the population, so that the relative incidence of occurrences, distribution and relationship relationship between variables, sociological and psychological.

Research was done by collecting qualitative data, which then presented in the form of numbers (quantified) to be tested verifikatif in accordance with the data analysis design.

\section{RESULT AND DISCUSSION}

\section{1 The Research Results}

The result of the SPSS estimation version 17, each research indicator, need to be explained further. This explanation is necessary because each variable is 
measured indirectly, but is formed by a number of indicators that need to be explored for its role to form the variable variables. For more details, will be discussed in each hypothesis.

As a result of calculation using SPSS version 17 program seen in recavitulation table result of correlation calculation between indevenden variable to devenden variable as follows:

Table 1. Recapitulation Result of correlation calculation between independent variable to dependent variable

\begin{tabular}{|l|c|c|c|}
\hline \multicolumn{1}{|c|}{ Variable } & $\begin{array}{c}\text { Correlation } \\
(\mathbf{r})\end{array}$ & $\begin{array}{c}\text { t/f } \\
\text { count }\end{array}$ & $\begin{array}{c}\text { p- } \\
\text { value }\end{array}$ \\
\hline $\begin{array}{l}\text { Quality of Service to } \\
\text { Customer Loyalty }\end{array}$ & 0,619 & 3,421 & 0,000 \\
\hline
\end{tabular}

Source; Results of SPSS Processing

Based on table 1, it can be seen that the independent variable has a high enough correlation level to the dependent variable. For further research, it will discuss how the influence of independent variables to the dependent variable. Moreover, the writer will discuss how the results of hypothesis testing work which has been predicted on the preliminary investigator in this article.

\section{2 DiscussionThe Effect of Service Quality (X) on Customer Loyalty (Y)}

Testing the influence of Service Quality (X) on Customer Loyalty (Y) is done by calculation as follows:

Coefficient of Determination (KD)

$=\mathrm{r}^{2} \times 100$

$=0,619^{2} \times 100$

$=38,30 \%$

Therefore, Customer Loyalty is affected by Quality service of $38.30 \%$. This means that Customer Loyalty is affected by a small portion of Service Quality of $38.30 \%$. The magnitude of the direct effect of service quality on customer loyalty is only $38.30 \%$, thus customer loyalty is influenced by other factors, namely $100 \%-38.30 \%=61.70 \%$. This means that Customer Loyalty is still largely influenced by other factors such as the quality of services provided by competitors, types of products or services purchased by consumers, as well as internal factors found in consumers such as consumer behavior itself. These factors are not the authors carefully so that it becomes the material of the next researcher both to be done by researchers and other researchers.

While to test the hypothesis by comparing thtung with tcritic namely: $3.421>1.667$. Testing Criteria:

- Reject $H_{o}$ if $t_{\text {count }}>t_{\text {table, meaning }}$ significant correlation coefficient and the influence of Quality of Service to Customer loyalty.

- Reject $\mathrm{H}_{\mathrm{o}}$ if $\mathrm{t}_{\text {count }}<\mathrm{t}_{\text {table, }}$ meaning correlation coefficient is not significant and there is no influence from service quality to customer loyalty.

Thus $t_{\text {count }}>t_{\text {table }}$ is $3.421>1.667$. Then the null hypothesis $\left(\mathrm{H}_{\mathrm{o}}\right)$ is rejected. This means that the quality of service positively influence on customer loyalty. Therefore, the working hypothesis can be accepted and tested its truth.

\section{CONCLUSION}

Based on the results of descriptive analysis and hypothesis testing that has been described in the previous discussion, it can be drawn conclusions in this article as follows: Quality of service based on the perception of the modern market customers are in the Good category. By using SPSS calculation, it is found that Service Quality Variables have bigger than tcritic, all indicator of service quality is significant. Based on correlation coefficient test that quality of service is positive and significant to customer loyalty. It means the better and the right quality of service will be more loyal consumers. The working hypothesis is well-tested and has a significant significance level because $p$-value is 0.0000 . 


\section{REFERENCES}

Blaekwell., D., Rogers., Paul W., Miniard, and James F. Engel, 2001, Consumer Behavior, Orlando: The Dryden Press Harcourt Brace College Publisher.

Christina Whidya Utami, 2006, Manajemen Ritel Strategi dan Implementasi Ritel Modern, Penerbit Salemba Empat, Jakarta

Fandy Tjiptono, 2008, Strategi Pemasaran, Yogyakarta: Andi Offset.

Griffin, Jill. 1995. Customer Loyalty : How to Earn It, How to Keep It. USA : Lexington Books.

Hawkin, Del I, Roger J. Best, and Kenneth A. Coney, 2000, Consumer Behaviour, Building Marketing Strategy, Eight Edition, McGraw-Hill, United State.

Horovitz, Jacques, 2000, Seven Secrets of Service Strategy, Prentice Hall, Hrlow, England.

Kotler, Philip, Keller, Kevin, Lane. 2009, Marketing Management : Pearson, Education, Inc. Upar Suddle River, New Jersey, 07458.

Walker, Orville, C., Harper W., Boyd, and Jean Claude Larreche, 1999, Marketing Strategy: Planning and Implementation, Third Edition, Irwin Mc. Graw Hill, Boston.

Zeithaml A., Valarie dan A. Parasuraman, Leonard L. Berry, 1990, Delivering Quality Service, Balancing Customer Perceptions and Expectations, New York : The Free Press, A. Division Of Macmillan, Inc., 